\title{
Efficacy of fungicides against damping-off in papaya seedlings caused by Pythium aphanidermatum
}

\author{
M. F. Male $\mathrm{A}^{\mathrm{B}}$ and L. L. Vawdrey ${ }^{\mathrm{A}}$ \\ APlant Pathology, Department of Employment, Economic Development and Innovation, Centre for Wet Tropics \\ Agriculture, South Johnstone, 4859 Qld, Australia. \\ ${ }^{\mathrm{B}}$ Corresponding author. Email: mike.male@deedi.qld.gov.au
}

\begin{abstract}
Various chemical and non-chemical treatments were tested for their efficacy against damping-off in papaya seedlings caused by Pythium aphanidermatum. Three-week-old papaya seedlings were placed in a climate controlled experimental chamber and inoculated with macerated mycelium of $P$. aphanidermatum. Propamocarb as Previcur was found to be most effective at managing damping-off in papaya seedlings.
\end{abstract}

Pythium aphanidermatum is an aggressive, cosmopolitan soilborne fungal pathogen with a wide host range. It is known to cause damping-off, root and stem rots and blights of fruit and grasses (van der Plaats-Niterink 1981). In northern Queensland, it is economically important as it causes damping-off in papaya (Carica papaya) (Teakle 1960). The establishment of new papaya plantings during winter requires that containerised seedlings are grown during the warm and often wet autumn months. These conditions favour the development of damping-off of young seedlings (Adams 1971). At present, limiting infection by $P$. aphanidermatum is based on cultural controls such as growing seedlings on raised benches in pasteurised media free of soil and plant material, and regulating irrigation. There are no chemicals registered for the control of damping-off in containerised papaya seedlings (Infopest 2003). Previous unpublished studies examining chemical control options for damping-off and other oomycete fungal pathogens of papaya identified several possible candidate compounds. This paper reports on the results of two in vivo experiments which evaluated the efficacy of a range of chemicals for the control of damping-off caused by $P$. aphanidermatum.

Papaya seeds (cultivar 1B) were sown into $100 \mathrm{~mm}$ diameter squat pots and thinned to eight plants per pot following germination. At 3 weeks of age, seedlings were placed in a climate-controlled experimental chamber and maintained at $30^{\circ} \mathrm{C}$, $>90 \%$ relative humidity and exposed to $14 \mathrm{~h}$ of light per day, in a completely randomised design. An isolate (BRIP 53639) of $P$. aphanidermatum (L. Tesoriero, pers. comm.) previously stored under sterile water was revived on culture plates of $2 \%$ potato dextrose agar amended with streptomycin sulfate and incubated in the dark at $27^{\circ} \mathrm{C}$. Axenic broth cultures were produced by transferring $5 \mathrm{~mm}$ plugs from the margin of the fungal colony to potato dextrose broth and then placed in an incubator in the dark at $27^{\circ} \mathrm{C}$ for 5 days. Mycelial mats were then rinsed with distilled water, weighed and macerated in distilled water in a Waring blender (Torrington, CT, US) for $20 \mathrm{~s}$. In each experiment, the equivalent of $1 \mathrm{~g}$ of mycelium suspended in
$50 \mathrm{~mL}$ of distilled water was used to inoculate each pot $48 \mathrm{~h}$ after placement in the climate control chamber.

All treatments (Table 1) except Bacillus+silica as Parkway Blend + Autofert (Barmac Pty. Ltd., Blackstone, Qld, Australia), metalaxyl-M as Ridomil Gold 25G (Syngenta Crop Protection Pty. Ltd., Macquarie Park, NSW, Australia) and acibenzolar-smethyl as Boost 500SC (Syngenta) were applied as a pot drench with a watering can several hours after inoculation with $P$. aphanidermatum. In experiment 1, Bacillus + silica was applied as a drench $24 \mathrm{~h}$ before inoculation and acibenzolar-smethyl was applied as a $24 \mathrm{~h}$ seed soak before sowing. In experiment 2, Bacillus + silica was applied as a drench 0,12 and 28 days after sowing. Granules of metalaxyl-M as Ridomil Gold $25 \mathrm{G}$ were thoroughly incorporated into the potting media before sowing. In preliminary research, metalaxyl-M as Ridomil Gold 480EC was found to be phytotoxic to papaya leaves, so plants receiving this treatment had their leaves rinsed with a small quantity of water immediately after the application. Untreated controls were treated with distilled water only. Plant mortality was recorded daily from the first day of symptom expression until no further plants died. Data was analysed with one-way analysis of variance (ANOVA) and pair-wise testing was performed

Table 1. List of fungicides tested for efficacy against damping-off caused by Pythium aphanidermatum in three-week-old papaya seedlings

\begin{tabular}{lll}
\hline Fungicide & Trade name & Supplier \\
\hline Metalaxyl-M drench & Ridomil Gold 480EC & Syngenta \\
Propamocarb & Previcur & Bayer CropScience \\
Furalaxyl & Fongarid 250WP & Garden King \\
Potassium phosphonate & Agrifos Supa 600 & Agrichem \\
Thiophanate methyl & Banrot & Scotts \\
Metalaxyl-M granule & Ridomil Gold 25G & Syngenta \\
Bacillus + silica & Parkway Blend + Autofert & Barmac \\
Acibenzolar-s-methyl & Boost 500SC & Syngenta \\
Dimethomorph & Acrobat SC & Nufarm \\
\hline
\end{tabular}


between treatment means using the protected least significance difference test.

Results from each experiment (Table 2) showed that propamocarb as Previcur (Bayer CropScience Pty. Ltd., Hawthorn, Vic., Australia), furalaxyl as Fongarid 250WP (Garden King Products Pty. Ltd., Parramatta, NSW, Australia) and metalaxyl-M as Ridomil Gold 480EC (Syngenta) provided an acceptable level of control of damping-off caused by

Table 2. Efficacy of fungicides on the percentage mortality of 3-weekold papaya seedlings artificially infested with Pythium aphanidermatum

\begin{tabular}{lccc}
\hline Treatment & $\begin{array}{c}\text { Application } \\
\text { rate }(\mathrm{g} \mathrm{a} . \mathrm{i} / \mathrm{L})^{\mathrm{A}}\end{array}$ & $\begin{array}{c}\text { Experiment 1 } \\
\text { mortality }(\%)^{\mathrm{B}, \mathrm{C}}\end{array}$ & $\begin{array}{c}\text { Experiment 2 } \\
\text { mortality }(\%)^{\mathrm{B}, \mathrm{C}}\end{array}$ \\
\hline Uninoculated control & - & $0.0 \mathrm{a}$ & - \\
Inoculated control & - & $74.6 \mathrm{bc}$ & $83.3 \mathrm{c}$ \\
Metalaxyl-M drench & 0.12 & $0.0 \mathrm{a}$ & $2.08 \mathrm{a}$ \\
Propamocarb & 0.9 & $0.0 \mathrm{a}$ & $2.08 \mathrm{a}$ \\
Furalaxyl & 0.25 & - & $6.25 \mathrm{ab}$ \\
Potassium phosphonate & 6.0 & $0.0 \mathrm{a}$ & $27.1 \mathrm{~b}$ \\
Thiophanate methyl & 1.2 & $51.1 \mathrm{~b}$ & - \\
Metalaxyl-M granule & $0.00625^{\mathrm{D}}$ & - & $79.2 \mathrm{c}$ \\
Bacillus + silica & $10.0+0.2$ & $65.4 \mathrm{bc}$ & $79.2 \mathrm{c}$ \\
Acibenzolar-s-methyl & 0.025 & $80.0 \mathrm{c}$ & - \\
Dimethomorph & 0.36 & - & $91.7 \mathrm{c}$ \\
s.e.m. & & 9.84 & 8.19 \\
l.s.d. & & 28.51 & 23.52 \\
\hline
\end{tabular}

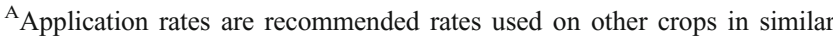
situations.

${ }^{\mathrm{B}}$ Means with the same lower case letters within the same column are not significantly different at the $P=0.05$ level.

${ }^{\mathrm{C}}$ Means are the total percentage mortality at the conclusion of each trial.

${ }^{\mathrm{D}}$ Application rate is the quantity of active ingredient per litre of potting mix.
P. aphanidermatum. Potassium phosphonate provided a variable level of control and the remainder of the treatments were ineffective.

The systemic fungicides furalaxyl and metalaxyl-M have been shown to be prone to resistance in Pythium aphanidermatum (Sanders and Soika 1988) and Phytophthora palmivora (Lucas et al. 1990). Metalaxyl-M is currently used in papaya at transplanting for the control of Phytophthora root rot. Due to the potential risk of biodegradation and fungicide resistance with the additional use of these chemicals, propamocarb was recommended to the Australian Pesticides and Veterinary Medicines Authority for registration as a chemical control for damping-off in papaya seedlings.

\section{References}

Adams PB (1971) Pythium aphanidermatum oospore germination as affected by time, temperature and $\mathrm{pH}$. Phytopathology 61, 1149-1150. doi:10.1094/Phyto-61-1149

Infopest (2003) 'Infopest-pest management information system.' (CDROM) (Department of Primary Industries: Brisbane)

Lucas JA, Bower LA, Coffey MD (1990) Fungicide resistance in soil-borne Phytophthora species. EPPO Bulletin 20, 199-206. doi:10.1111/j.13652338.1990.tb01199.x

Sanders PL, Soika MD (1988) Metalaxyl resistance frequency in overwintering populations of Pythium aphanidermatum from metalaxyl control failure sites. Phytopathology 78, 1510.

Teakle DS (1960) Species of Pythium in Queensland. Queensland Journal of Agricultural Science 17, 15-31.

van der Plaats-Niterink AJ (1981) Monograph of the genus Pythium. Studies in Mycology 21, 1-24.

Manuscript received 7 September 2010, accepted 13 September 2010 